\title{
ERRATUM
}

\section{High sedimentary oxygen consumption indicates that sewage input from small islands drives benthic community shifts on overfished reefs - ERRATUM}

\author{
AMANDA K. FORD, NANNE VAN HOYTEMA, BRADLEY R. MOORE, LINA PANDIHAU, \\ CHRISTIAN WILD AND SEBASTIAN C. A. FERSE
}

doi:10.1017/S0376892917000054, Published by Cambridge University Press, 28 February 2017. First published online 27 March 2017.

In the article above there is a spelling mistake in the Figure 3 legend. Largge should be Large. The correct Figure 3 legend is shown below:-

Figure 3 Biomass values of herbivorous fish functional groups - browsers, grazers and detritivores, and scrapers and small excavators - for each island. Large excavators and bioeroders were not observed, and thus are not included in the graph.

Page 5, right column in the 'Ecological perspective and management implications section', in the second paragraph the third sentence should read ... One potential management tool that considers these needs and limitations is the installation of composting toilets, after due consideration of local cultural sensitivities ...

The publisher apologises for these errors.

\section{Reference}

Ford, A. K. et al. High sedimentary oxygen consumption indicates that sewage input from small islands drives benthic community shifts on overfished reefs. Environmental Conservation. Published by Cambridge University Press, 28 February 2017. doi: $10.1017 /$ S0376892917000054 